\title{
Porównywalność w badaniach zjawiska oportunizmu
}

Dr inż. Iwona Staniec iD

Politechnika Łódzka Wydział Zarządzania i Inżynierii Produkcji Katedra Zarządzania

\section{Wprowadzenie}

Wszechobecna cyfryzacja wywiera coraz silniejszy wpływ na reguły współpracy międzyorganizacyjnej, oferując nowe modele biznesowe, umożliwiające przechwytywanie wartości na każdym etapie łańcucha wartości oraz zdobywanie przewagi konkurencyjnej. Angażowanie się w zarządzanie cyfrowe wymaga od organizacji wykorzystywania gromadzonych danych w odpowiedzialny i bezpieczny sposób oraz zapewnienia ich transparentności i wiarygodności. Cyfryzacja głęboko modyfikuje strategiczne podejście do współpracy międzyorganizacyjnej. Nauki o zarządzaniu stawiają sobie współcześnie za jeden z celów opracowanie teorii pozwalającej na wyjaśnienie zjawisk międzyorganizacyjnych w dobie cyfrowej gospodarki sieciowej, a jednym z nich są zachowania oportunistyczne. Oportunizm został zdefiniowany przez Williamsona ${ }^{1}$ jako tendencja do podstępnego zachowania prowadzącego do wyraźnego etycznego naruszenia umowy o współpracy lub norm relacyjnych. Przytoczona definicja wskazuje na jego abstrakcyjną koncepcję, przyjmuje on zatem postać konstruktu², dla którego poszukiwany jest przejaw empiryczny. Operacjonalizacja konstruktu umożliwia testowanie teorii, czyli wyposaża badacza w zdolność predykcji natężenia czy zmiany badanego zjawiska, a praktyków w zdolność podejmowania lepszych działań3. Jedną z wad badań w naukach o zarządzaniu jest brak rygoru metodologicznego oraz rzetelnego narzędzia pomiarowego ${ }^{4}$. Wielokrotna walidacja konstruktu przez różnych badaczy

1 O.E. Williamson, The Economic Institutions of Capitalism, The Free Press, New York 1985.

2 W. Czakon, Tworzenie teorii w naukach o zarządzaniu, [w:] A. Sopińska, P. Wachowiak (red.), Wyzwania wspótczesnego zarzq̨dzania strategicznego, Oficyna Wydawnicza SGH - Szkoła Główna Handlowa w Warszawie, Warszawa 2017, s. 143-160.

3 W. Czakon, Walidacja narzędzia pomiarowego w naukach o zarzq̨dzaniu, „Przegląd Organizacji" 2019, nr 4, s. 3-10, http://dx.doi.org/10.33141/po.2019.04.01

4 Tamże, s. 6. 
w różnych kontekstach prowadzi do uznania narzędzia pomiarowego i zwalnia kolejnych badaczy z konieczności przeprowadzania szczegółowych testów walidacyjnych, co ułatwia badania replikacyjne i porównywanie badanych zjawisk. W zakresie oportunizmu interesujące jest to, jak badacze od 1985 roku radzili sobie z pomiarem tego zjawiska oraz czy zostało stworzone narzędzie pomiaru pozwalające na replikacyjność tych badań. Celem rozdziału jest przedstawienie analizy porównawczej wybranych prac dotyczących empirycznego pomiaru zjawiska oportunizmu. W opracowaniu przyjęto dobór celowy, a za kryteria analizy porównawczej uznano: zdefiniowanie konstruktu, zastosowane narzędzia pomiaru, przyjętą skalę pomiarową, wskaźniki decydujące o trafności i rzetelności pomiaru, uzyskane wartości oportunizmu. Rozdział ma charakter przeglądowy i jest oparty na badaniu praktyk stosowanych w zakresie operacjonalizacji pomiaru oportunizmu.

\section{Metodyka badań}

W opracowaniu zastosowano badania bibliometryczne, rozumiane jako wykorzystanie analiz ilościowych i jakościowych do przeglądu publikacji pod względem liczebności i zawartości tematycznej z wykorzystaniem analizy treści. Obiektem prowadzonych badań są artykuły naukowe, a przedmiotem zastosowana w nich operacjonalizacja konstruktu oportunizmu oraz wyniki jego pomiaru. Badania uwzględniały analizy ilościowe dotyczące częstości poszczególnych wskazań, porównywania otrzymanych wartości oraz analizy jakościowe związane ze zdefiniowaniem konstruktu, opisem operacjonalizacji skali pomiaru oraz zastosowanymi technikami walidacji 5 . Dokonano celowego doboru obiektów do badań - ze względu na prowadzone badania porównawcze, w których istotne są cechy charakterystyczne tylko dla pewnych publikacji dotyczących oportunizmu6. W dalszej kolejności dla wybranych obiektów zastosowano analizę treści ${ }^{7}$, czyli metodę niewymagającą wchodzenia $\mathrm{w}$ bezpośrednią interakcję badacza $\mathrm{z}$ badanymi, gdyż badane są istniejące już zawartości opublikowanych artykułów naukowych. Analizie treści, jako metodzie badawczej, przypisuje się ilościowy i jakościowy charakter. Charakter ilościowy polega na zliczaniu określonych, występujących w badanym materiale elementów lub cech, a jakościowy na wielokrotnej analitycznej lekturze tekstów, zmierzającej do strukturyzacji poruszanych w nich tematów

5 W. Czakon, Metodyka systematycznego przeglądu literatury, „Przegląd Organizacji” 2011, nr 3, s. 57-61.

6 E. Babbie, Badania spoteczne w praktyce, Wydawnictwo Naukowe PWN, Warszawa 2003.

7 Została zdefiniowana przez Bernarda Berelsona (B. Bernstein, Socjolingwistyka a społeczne problemy kształcenia, [w:] M. Głowiński (red.), Język i społeczeństwo, Wydawnictwo Czytelnik, Warszawa 1980, s. 83-116), a opisana również w pracy Czakona, Metodyka.... 
i prezentowanych treści. Efektem analitycznego podejścia jest stworzenie klucza kategoryzacyjnego, będącego ustrukturyzowanym zbiorem kategorii tematycznych zawartych w artykułach. W prowadzonym badaniu, zgodnie z zasadami analizy porównawczej, za klucze kategoryzacyjne przyjęto: definicję konstruktu oportunizmu, metody i techniki operacjonalizacji, skale pomiarowe oraz uzyskane wartości pomiaru. Warto również zauważyć, że w tak prowadzonych badaniach wnioski mogą dotyczyć tylko zbioru analizowanych tekstów, postrzeganych jako całość ${ }^{8}$. Wadą analizy treści jest brak obiektywizmu, który jest przy jej użyciu jedynie postulatem mającym podkreślić konieczność unikania wszelkiej arbitralności i subiektywizmu. W krytyce tego podejścia podkreśla się również brak możliwości replikacji ${ }^{9}$.

\section{Charakterystyka obiektów poddanych badaniu}

W ramach doboru obiektów do badania wykorzystano publikacje zaindeksowane w bazie EBSCO oraz w bazie danych Business Source Ultimate. Obiekty do analizy wybrano ${ }^{10}$, wyodrębniając artykuły naukowe ze słowem kluczowym „opportunism”. Następnie zawężono ich wybór do pełnotekstowych publikacji w czasopismach naukowych w języku angielskim, uporządkowanych według oferowanego kryterium „trafności”. Z wylistowanych w ten sposób 205 prac wybrano te, które w treści zawierały badania empiryczne dotyczące zjawiska oportunizmu. Z góry założono ${ }^{11}$, że ich liczebność - ze względu na prowadzone analizy porównawcze - nie może być większa niż 20. Wybór zakończono zatem, gdy lista wybranych w kolejności wylistowania prac osiągnęła wartość 20 . W kolejnym etapie uporządkowano je chronologicznie (tabela 1) i poddano dalszemu badaniu.

Wszystkie zaprezentowane $\mathrm{w}$ pracach $\mathrm{z}$ tabeli 1 badania prowadzone były $\mathrm{w}$ formie kwestionariuszowej: dwa $\mathrm{z}$ nich to wywiady ${ }^{12}$, dwa to obserwacje

8 K. Szczepaniak, Zastosowanie analizy treści w badaniach artykutów prasowych - refleksje metodologiczne, „Acta Universitatis Lodziensis. Folia Sociologica” 2012, nr 42, s. 85; W. Czakon, Metodyka..., s. 60.

9 K. Szczepaniak, Zastosowanie analizy treści..., s. 87.

10 Wybór dokonywany był w czerwcu 2019 roku. Ze względu na dynamikę bazy powtórzenie identycznego wyszukiwania jest niemożliwe.

11 Założenie wynika z subiektywizmu autora.

12 C. Zhang, J. Li, Y. Huang, Sustaining relationships after opportunism and misunderstanding: the role of formalization and socialization, „Marketing Letters” 2017, vol. 28(2), s. 305-319, http://doi.org/10.1007/s11002-016-9414-1; A. Verbeke, L. Ciravegnad, L.E. Lopeze, S.K. Kunduf, Five Configurations of Opportunism in International, Market Entry, „Journal of Management Studies" 2018, http://doi.org/10.1111/joms.12355 
nieuczestniczące ${ }^{13}$, a pozostałe to badania ankietowe prowadzone technikami CATI lub CAWI. Minimalna próba, na jakiej prowadzono eksperymenty, liczyła 65 przy obserwacji ${ }^{14}, 100$ w badaniach ankietowych ${ }^{15}$, a maksymalna $608^{16}$. Osiem badań dotyczyło obszaru USA, sześć Chin, a tylko dwa Europy: Norwegii i Holandii. Wszystkie badania skupiały się na percepcji respondenta, a nie faktycznych zachowaniach czy bezpośrednio mierzalnych zjawiskach.

Tabela 1. Uporządkowane chronologicznie publikacje poddane badaniu

\begin{tabular}{|c|c|c|c|c|c|}
\hline Lp. & Autor & Kontekst empiryczny & Oportunizm & $\begin{array}{l}\text { Liczba } \\
\text { pytań }\end{array}$ & $\begin{array}{l}\text { Skala } \\
\text { Likerta }\end{array}$ \\
\hline 1 & $\begin{array}{l}\text { John } \\
(1984)\end{array}$ & $\begin{array}{l}\text { Badanie mailowe sprzedawców } \\
\text { dużej firmy naftowej } n=147\end{array}$ & $\begin{array}{l}\text { Williamson (1979), } \\
\text { Brown i Day (1981) }\end{array}$ & 6 & $5 \mathrm{pkt}$ \\
\hline 2 & $\begin{array}{l}\text { Gundlach, } \\
\text { Achrol } \\
\text { i Mentzer } \\
\text { (1995) }\end{array}$ & $\begin{array}{l}\text { Producent }(P) \text { i dystrybutor }(D) \\
\text { w branży komputerowej (symulacja } \\
\text { na studentach) } n=65\end{array}$ & $\begin{array}{l}\text { Goetz i Scott (1981), } \\
\text { Muris (1981), } \\
\text { Williamson (1985) }\end{array}$ & 6 & $7 \mathrm{pkt}$ \\
\hline 3 & $\begin{array}{l}\text { Achrol } \\
\text { i Gundlach } \\
(1999)\end{array}$ & $\begin{array}{l}\text { Producent-dystrybutor w branży } \\
\text { komputerowej (symulacje } \\
z \text { wykorzystaniem studentów), USA } \\
n=101\end{array}$ & $\begin{array}{l}\text { Williamson (1985), } \\
\text { Gundlach, Achrol } \\
\text { i Mentzer (1995) }\end{array}$ & 6 & $7 \mathrm{pkt}$ \\
\hline 4 & $\begin{array}{l}\text { Dahlstrom } \\
\text { i Nygaard } \\
\text { (1999) }\end{array}$ & $\begin{array}{l}\text { Ankieta mailowa, producenci ropy, } \\
\text { Norwegia (1990) } n=179,(1994) \\
n=117\end{array}$ & $\begin{array}{l}\text { John (1984), } \\
\text { Williamson (1985), } \\
\text { Anderson (1988) }\end{array}$ & 2 & $7 \mathrm{pkt}$ \\
\hline 5 & $\begin{array}{l}\text { Brown, } \\
\text { Dev i Lee } \\
(2000)\end{array}$ & $\begin{array}{l}\text { Ankieta mailowa, respondenci } \\
\text { menedżerowie hotelu, USA, } n=368\end{array}$ & $\begin{array}{l}\text { John (1984), } \\
\text { Dwyer i Oh (1987), } \\
\text { Anderson (1988), } \\
\text { Provan i Skinner } \\
\text { (1989) }\end{array}$ & $10(5)$ & $7 \mathrm{pkt}$ \\
\hline 6 & $\begin{array}{l}\text { Gilliland } \\
\text { i Manning } \\
(2002) \\
\end{array}$ & $\begin{array}{l}\text { Ankieta mailowa, badani } \\
\text { właściciele restauracji lub } \\
\text { menedżerowie, USA, } n=173 \\
\end{array}$ & $\begin{array}{l}\text { John (1984), } \\
\text { Dahlstrom i Nygaard } \\
\text { (1999) }\end{array}$ & 3 & $5 \mathrm{pkt}$ \\
\hline 7 & $\begin{array}{l}\text { Rokkan, } \\
\text { Heide } \\
\text { i Wathne } \\
(2003)\end{array}$ & $\begin{array}{l}\text { Badanie par dostawca (D) } \\
\text { - kupujący (K) w branży } \\
\text { komputerowej, } n=198 \text { par }\end{array}$ & $\begin{array}{l}\text { John (1984), } \\
\text { Anderson (1988), } \\
\text { Brown, Dev i Lee } \\
(2000)\end{array}$ & 6 & $7 \mathrm{pkt}$ \\
\hline
\end{tabular}

13 G.T. Gundlach, R.S. Achrol, J.T. Mentzer, The Structure of Commitment in Exchange, „Journal of Marketing" 1995, no. 59(January), s. 78-92; R.S. Achrol, G.T. Gundlach, Legal and Social Safeguards Against Opportunism in Exchange, „Journal of Retailing” 1999, vol. 75(1), s. 107-124.

14 G.T. Gundlach, R.S. Achrol, J.T. Mentzer, The Structure of Commitment...

15 S. Wuyts, I. Geyskens, The Formation of Buyer - Supplier Relationships: Detailed Contract Drafting and Close Partner Selection, „Journal of Marketing” 2005, no. 69(October), s. 103-117.

16 W przypadku wywiadów w pracy C. Zhang, J. Li, Y. Huang, Sustaining relationships... 


\begin{tabular}{|c|c|c|c|c|c|}
\hline Lp. & Autor & Kontekst empiryczny & Oportunizm & $\begin{array}{l}\text { Liczba } \\
\text { pytań }\end{array}$ & $\begin{array}{l}\text { Skala } \\
\text { Likerta }\end{array}$ \\
\hline 8 & $\begin{array}{l}\text { Jap } \\
\text { i Anderson } \\
(2003)\end{array}$ & $\begin{array}{l}\text { Ocena relacji z dwóch stron: } \\
\text { dział zaopatrzenia czterech } \\
\text { firm produkcyjnych Fortune } \\
50: \text { IT, sprzętu fotograficznego, } \\
\text { producenta chemicznego oraz ich } \\
\text { bezpośredni klienci, } n=321\end{array}$ & $\begin{array}{l}\text { Brown, Dev i Lee } \\
(2000)\end{array}$ & 8 & $7 \mathrm{pkt}$ \\
\hline 9 & $\begin{array}{l}\text { Wuyts } \\
\text { i Geyskens } \\
(2005)\end{array}$ & $\begin{array}{l}\text { Badanie menedżerów zakupów } \\
\text { w przemyśle maszynowym, } \\
\text { elektronicznym i elektrycznym, } \\
\text { Holandia, } n=100\end{array}$ & $\begin{array}{l}\text { Gundlach, Achrol } \\
\text { i Mentzer (1995), } \\
\text { Dahlstroma } \\
\text { i Nygaarda (1999) }\end{array}$ & 4 & $7 \mathrm{pkt}$ \\
\hline 10 & \begin{tabular}{|l|} 
Heide, \\
Wathne \\
i Rokkan \\
$(2007)$ \\
\end{tabular} & $\begin{array}{l}\text { Ankieta pocztowa (dwie } \\
\text { fale), menedżerowie } z \text { firmy } \\
\text { budowlanych, USA, } n=129 \text { (o1) } \\
\text { i } n=213 \text { (o2) }\end{array}$ & $\begin{array}{l}\text { John (1984), } \\
\text { Gundlach, Achrol } \\
\text { i Mentzer (1995) }\end{array}$ & 6 & $7 \mathrm{pkt}$ \\
\hline 11 & Jap (2007) & $\begin{array}{l}\text { Analiza } 125 \text { quasi-eksperymentów } \\
\text { z udziałem } 25 \text { dostawców z listy } \\
\text { Fortune } 100 \text { i } 385 \text { milionów } \\
\text { USD na zamówienia publiczne. } \\
\text { Zamówienia były składane on-line } \\
(n=125)\end{array}$ & $\begin{array}{l}\text { Williamson (1996), } \\
\text { Brown, Dev i Lee } \\
\text { (2000), Wathne } \\
\text { i Heide (2000), Jap } \\
\text { i Anderson (2003) }\end{array}$ & 8 & $7 \mathrm{pkt}$ \\
\hline 12 & $\begin{array}{l}\text { Kashyap, } \\
\text { Antia } \\
\text { i Frazier } \\
(2012) \\
\end{array}$ & $\begin{array}{l}\text { Ankieta mailowa, przemyst } \\
\text { samochodowy, franczyzobiorcy, } \\
n=234 \text { USA }\end{array}$ & $\begin{array}{l}\text { Brown, Dev i Lee } \\
(2000)\end{array}$ & 7 & $7 \mathrm{pkt}$ \\
\hline 13 & $\begin{array}{l}\text { Seggie, } \\
\text { Griffith } \\
\text { i Jap } \\
(2013)\end{array}$ & $\begin{array}{l}\text { Listy kupujących z } 4 \text { firm } \\
\text { produkcyjnych z listy Fortune } \\
\text { 50, ankieta pocztowa, } n=193 \text {. } \\
\text { Zastosowano podział na aktywny } \\
\text { (a) i pasywny (p) oportunizm }\end{array}$ & $\begin{array}{l}\text { Jap } \\
\text { i Anderson (2003) }\end{array}$ & 6 & $7 \mathrm{pkt}$ \\
\hline 14 & $\begin{array}{l}\text { Yan i Kull } \\
(2015)\end{array}$ & $\begin{array}{c}\text { Badania ankietowe relacji kupujący } \\
\text { - dostawca nowej technologii, } \\
n=416 \text { (USA 206, Chiny 210) }\end{array}$ & $\begin{array}{l}\text { Jap i Anderson } \\
\text { (2003) }\end{array}$ & 8 & $7 \mathrm{pkt}$ \\
\hline 15 & $\begin{array}{l}\text { Crosno } \\
\text { i Dahlstrom } \\
(2016)\end{array}$ & $\begin{array}{l}\text { Badanie ankietowe menedżerów } \\
\text { sklepów detalicznych z branży } \\
\text { elektroniki użytkowej (K) } \\
\text { i dostawców (D), Norwegia, } n=120\end{array}$ & John (1984) & 4 & $7 \mathrm{pkt}$ \\
\hline 16 & $\begin{array}{l}\text { Lianying } \\
\text { i Qinzhen } \\
(2017)\end{array}$ & $\begin{array}{l}\text { Badania ankietowe relacji } \\
\text { właściciel - podwykonawca } \\
\text { w przemyśle budowlanym, Chiny, } \\
n=156\end{array}$ & $\begin{array}{l}\text { Heide, Wathne } \\
\text { i Rokkan (2007), Lu, } \\
\text { Zhang i Zhang (2016) }\end{array}$ & 8 & $7 \mathrm{pkt}$ \\
\hline 17 & $\begin{array}{l}\text { Zhang, } \\
\text { Li i Huang } \\
\text { (2017) }\end{array}$ & $\begin{array}{l}\text { Wywiady bezpośrednie w chińskich } \\
\text { firmach przemystowych, } n=304 \\
\text { firmy ( } 608 \text { wywiadów) }\end{array}$ & $\begin{array}{l}\text { Jap i Anderson } \\
\text { (2003) }\end{array}$ & 4 & $7 \mathrm{pkt}$ \\
\hline 18 & $\begin{array}{l}\text { Verbeke } \\
\text { i wsp. } \\
\text { (2018) }\end{array}$ & $\begin{array}{l}\text { Wywiady u } 38 \text { chińskich } \\
\text { eksporterów na temat ich } 133 \\
\text { wejść na nowe rynki }\end{array}$ & John (1984) & 6 & $7 \mathrm{pkt}$ \\
\hline
\end{tabular}


Tabela 1 (cd.)

\begin{tabular}{|c|l|l|l|c|c|}
\hline Lp. & \multicolumn{1}{|c|}{ Autor } & \multicolumn{1}{|c|}{ Kontekst empiryczny } & \multicolumn{1}{|c|}{ Oportunizm } & $\begin{array}{l}\text { Liczba } \\
\text { pytań }\end{array}$ & $\begin{array}{c}\text { Skala } \\
\text { Likerta }\end{array}$ \\
\hline 19 & $\begin{array}{l}\text { Um i Kim, } \\
(2018)\end{array}$ & $\begin{array}{l}\text { Badanie ankietowe firm } \\
\text { zaangażowanych w projekty } \\
\text { tworzenia nowych technologii, } \\
\text { Korea, } n=304\end{array}$ & $\begin{array}{l}\text { Skarmeas i wsp. } \\
(2002)\end{array}$ & 4 & 7 pkt \\
\hline 20 & $\begin{array}{l}\text { You i wsp. } \\
(2018)\end{array}$ & $\begin{array}{l}\text { Badania właścicieli i generalnych } \\
\text { wykonawców w chińskim } \\
\text { przemyśle budowlanym, } n=220\end{array}$ & $\begin{array}{l}\text { Luo (2006), Lu i wsp. } \\
(2015)\end{array}$ & 6 & 7 pkt \\
\hline
\end{tabular}

Źródło: opracowanie własne.

Na podstawie tych badań można zaobserwować trzy podejścia do analizy oportunizmu:

- najpowszechniejsze podejście to pytanie o zachowania oportunistyczne drugiej strony relacji; stosowane na przykład w badaniach Dahlstroma i Nyga$\operatorname{arda}^{17}$ oraz Wuytsa i Geyskens ${ }^{18}$;

- drugie podejście to pytanie respondentów o ich własne zachowania oportunistyczne ${ }^{19}$, czasami poprzez sformułowanie pytań niedotyczących aspektów etycznych ${ }^{20}$;

- trzecie to badanie par producent - dystrybutor ${ }^{21}$, dostawca - kupujący ${ }^{22}$, zaopatrzenie - klient ${ }^{23}$, właściciel - podwykonawca ${ }^{24}$; każdy wypowiada się na temat zachowania strony przeciwnej.

Jap i Anders ${ }^{25}$ jako jedyni stworzyli w swoich badaniach dodatkowo dwie grupy oportunizmu: wysoki (wskazania powyżej mediany) i niski (wskazania poniżej

17 R. Dahlstrom, A. Nygaard, An Empirical Investigation of Ex post Transaction Costs in Franchised Distribution Channels, „Journal of Marketing Research” 1999, no. 36(May), s. 160-170.

18 S. Wuyts, I. Geyskens, The Formation of Buyer...

19 Na przykład J.R. Brown, C.S. Dev, D.J. Lee, Managing Marketing Channel Opportunism: The Efficacy of Alternative Governance Mechanisms, „Journal of Marketing” 2000, no. 64(April), s. 51-65.

20 Na przykład G. John, An Empirical Investigation of Some Antecedents of Opportunism in a Marketing Channel, „Journal of Marketing Research” 1984, vol. 21(3), s. 278-289.

21 Na przykład G.T. Gundlach, R.S. Achrol, J.T. Mentzer, The Structure of Commitment...

22 Na przykład A.I. Rokkan, J.B. Heide, K.H. Wathne, Specific Investments in Marketing Relationships: Expropriation and Bonding Effects, „Journal of Marketing Research” 2003, no. 40(May), s. 210-224.

23 Na przyktad D.S. Jap, E. Anderson, Safeguarding interorganizational performance and continuity under ex post opportunism, „Management Science” 2003, vol. 49(12), s. 1684-1701.

24 Na przykład Z. Lianying, Q. Qinzhen, How mediated power affects opportunism in owner-contractor relationships: The role of risk perceptions, „International Journal of Project Management" 2017, vol. 35(3), s. 516-529.

25 D.S. Jap, E. Anderson, Safeguarding... 
mediany), w których analizowali odpowiednie zachowania. Natomiast Seggie i współautorzy ${ }^{26}$ mierzyli oddzielnie oportunizm aktywny i pasywny ${ }^{27}$, co nie jest spotykane w innych badaniach empirycznych.

\section{Definicja konstruktu}

Zgodnie $\mathrm{z}$ definicją Williamsona ${ }^{28} \mathrm{w}$ definiowaniu konstruktu oportunizm autorzy odnoszą się do poszukiwania własnych korzyści poprzez zachowanie charakteryzujące się wysiłkiem zmierzającym do wprowadzenia w błąd lub zmylenia partnerów. Autorzy badań prezentowanych w tabeli 1 szukali wyjaśnienia oportunizmu na gruncie teorii kosztów transakcyjnych i teorii wymiany relacyjnej. Przy definiowaniu oportunizmu odnosili się do prac: Williamsona ${ }^{29}$, Johna ${ }^{30}$, Andersona ${ }^{31}$, Provana i Skinnera ${ }^{32}$, Gundlacha, Achrola i Mentzera ${ }^{33}$, Dahlstroma i Nygaarda ${ }^{34}$, Browna i in. ${ }^{35}$, Wathnego i Heidego ${ }^{36}$, Jap i Andersona ${ }^{37}$, Luo ${ }^{38}$, Heidego, Wathnego i Rokkana ${ }^{39}$, Lu i współautorów ${ }^{40}$.

26 S.H. Seggie, D.A. Griffith, S. D. Jap, Passive and Active Opportunism in Interorganizational Exchange, „Journal of Marketing” 2013, vol. 77(6), s. 73-90, http://doi.org/10.1509/jm.11.0529

27 Na te rodzaje oportunizmu zwrócono uwagę w pracy J. Karpacz, Oportunizm w relacjach międzyorganizacyjnych w teorii i praktyce, „Prace Naukowe Uniwersytetu Ekonomicznego we Wrocławiu" 2014, nr 366, s. 236-247.

28 O.E. Williamson, The Economic Institutions...

29 O.E. Williamson, Transaction Costs Economics: The Governance of Contractual Relationships, ,Journal of Law and Economics" 1979, no. 22, s. 223-260; O.E. Williamson, The Economic Institutions...; O.E. Williamson, The Mechanisms of Governance, Oxford University Press, New York 1996.

30 G. John, An Empirical Investigation...

31 E. Anderson, Transaction Costs as Determinants of Opportunism in Integrated and Independent Sales Forces, „Journal of Economic Behavior and Organization” 1988, no. 9, s. 247-264.

32 K.G. Provan, S.J. Skinner, Interorganizational Dependence and Control as Predictors of Opportunism in Dealer-Seller Relations, „Academy of Management Journal” 1989, no. 32(March), s. 202-212.

33 G.T. Gundlach, R.S. Achrol, J.T. Mentzer, The Structure of Commitment...

34 R. Dahlstrom, A. Nygaard, An Empirical Investigation...

35 J.R. Brown, C.S. Dev, D.J. Lee, Managing Marketing Channel Opportunism...

36 K.H. Wathne, J.B. Heide, Opportunism in Interfirm Relationships: Forms. Outcomes, and Solutions, „Journal of Marketing” 2000, no. 64(October), s. 36-51.

37 D.S. Jap, E. Anderson, Safeguarding...

38 Y. Luo, Opportunism in interfirm exchange in emerging markets, „Management \& Organization Review" 2006, vol. 2(1), s. 121-147.

39 J.B. Heide, K.H. Wathne, A.I. Rokkan, Interfirm monitoring, social contracts, and relationship outcomes, „Journal of Marketing Research” 2007, vol. 44(3), s. 425-433.

40 P. Lu, L. Qian, Z. Chu, X. Xu, Role of opportunism and trust in construction projects: empirical evidence from China, „Journal of Management Engineering” 2015, vol. 32(2), s. 1-10. 


\section{Narzędzie pomiarowe}

W analizowanych badaniach stosowane skale pomiaru to skala Likerta, najczęściej siedmiopunktowa. W dwóch badaniach - Johna ${ }^{41}$ oraz Gillilanda i Manninga $^{42}$ - wystąpiła tylko pięciopunktowa skala. W badaniach stosowano dwie formy odpowiedzi:

- dotyczące częstości stosowania, czyli na przykład na pytanie „Kiedy pojawia się problem, jak często zrobi to...?” możliwe odpowiedzi to: 1 = „rzadko”, 7 = „bardzo często"43 lub czasami w ujęciu 1 = „bardzo mało prawdopodobne”, 7 = „bardzo prawdopodobne”"44;

- dotyczące zgody ze stwierdzeniem, czyli na przykład na stwierdzenie „Aby osiągnąć cele, konieczne okazuje się zaniedbywanie niektórych z naszych zobowiązań” pojawiające się odpowiedzi to: $1=$ „zdecydowanie nie zgadzam się" i 7 = „stanowczo się zgadzam” lub 1 = „całkowicie niedokładny opis” i 7 = „całkowicie dokładny opis” 45 .

Warto zatem zwrócić uwagę, że pytania są albo o częstość (prawdopodobieństwo) występowania określonych sytuacji, albo o opinię na temat zaistnienia konkretnych opisanych sytuacji w badanym aspekcie. Tak więc w wyniku niektórych badań otrzymujemy informację o natężeniu oportunizmu, a w innych o częstości jego występowania.

We wszystkich badaniach (porównaj tabela 1) oportunizm traktowano jako konstrukt wielowymiarowy, mierzony najczęściej na podstawie sześciu pytań (wykorzystano je w ośmiu z dwudziestu analizowanych badań). W przedstawionych pracach ich liczba waha się od dwóch do ośmiu. W pięciu badaniach pojawiły się tylko cztery pytania, a w czterech aż osiem pytań. Dwa, trzy i pięć pytań pojawiło się tylko w pojedynczych badaniach, a siedem nie wystąpiło ani razu. Liczba pytań w narzędziu pomiarowym jest zatem zróżnicowana.

41 G. John, An Empirical Investigation...

42 D.I. Gilliland, K.C. Manning, When Do Firms Conform to Regulatory Control? The Effect of Control Processes on Compliance and Opportunism, „Journal of Public Policy \& Marketing” 2002, no. 21, s. 319-331.

43 Na przykład w badaniach D.S. Jap, E. Anderson, Safeguarding... oraz S. D. Jap, The Impact of Online Reverse Auction Design on Buyer - Supplier Relationships, „Journal of Marketing” 2007, no. 71(January), s. 146-159.

44 Stosowanym na przykład w pracy T. Yan, T.J. Kull, Supplier Opportunism in Buyer-Supplier New Product Development: A China U.S. Study of Antecedents, Consequences, and Cultural/ Institutional Contexts, „Decision Sciences” 2015, vol. 46(2), s. 403-444.

45 Stosowane na przykład w pracach G. John, An Empirical Investigation... oraz A. Verbeke i wsp., Five Configurations... 
Wyraźnie widać, że autorzy dbają o powtarzalność badań (tabela 1), gdyż skala zbudowana przez Johna ${ }^{46}$ znalazła zastosowanie w jeszcze siedmiu analizowanych badaniach, przez Jap i Andersona ${ }^{47}$ w czterech badaniach, przez Gundlacha,

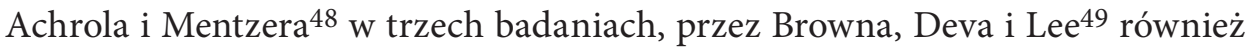
w trzech badaniach, przez Achrola i Gundlacha ${ }^{50}$ w dwóch badaniach, a przez $\mathrm{Jap}^{51} \mathrm{w}$ jednym badaniu. Stosowane w ramach pomiaru konstruktu pytania tylko nieznacznie różnią się między sobą. Autorzy łączą je, dostosowując do specyfiki badań, podmiotu, branży, rynku itp. Dotyczą one ogólnie: honorowania obietnic, opinii o współdziałaniu, utrzymania sprawiedliwości, przestrzegania norm negocjacyjnych, unikania bumelowania, cwaniactwa i podstępu.

W analizowanych badaniach wskazano, że istnieje zróżnicowane podejście do tworzonego narzędzia pomiarowego, polegające na wykorzystaniu pytań z poprzednich badań, których wiarygodność została zweryfikowana, lub dodaniu nowych ${ }^{52}$. Występuje zatem proces ciągłego poszukiwania narzędzia pomiarowego opartego na istniejących konstrukcjach, w celu poszerzenia percepcji zachowań, które można uznać za oportunistyczne oraz które pozwoliłoby na jednoznaczną porównywalność wyników.

W pracach przedstawiane są walidacje konstruktu. Zaprezentowane miary rzetelności to: współczynnik alfa Cronbacha oraz wartości AVE (average variance extracted) i CR (composite reliability) ${ }^{53}$. Tylko w badaniu Browna, Deva i Lee ${ }^{54}$ pokazano, że konstrukt miało stanowić dziesięć pytań, ale badania rzetelności i trafności wykluczyły pięć z nich. Tylko w dwóch badaniach podano procent wyjaśnienia wariancji ogółem dla wszystkich składowych narzędzia pomiarowego i był on wyższy niż $60 \%$.

46 G. John, An Empirical Investigation...

47 D.S. Jap, E. Anderson, Safeguarding...

48 G.T. Gundlach, R.S. Achrol, J.T. Mentzer, The Structure of Commitment...

49 J.R. Brown, C.S. Dev, D.J. Lee, Managing Marketing Channel Opportunism...

50 R.S. Achrol, G.T. Gundlach, Legal and Social Safeguards...

51 S. D. Jap, The Impact...

52 W pracy S. Kelly, B. Wagner, J. Ramsay, Opportunism in buyer - supplier exchange: a critical examination of the concept and its implications for theory and practice Production Planning \& Control, „The Management of Operations” 2018, vol. 29(12), s. 992-1009 http://doi.org /10.1080/09537287.2018.1495772 wskazano, że w pomiarze oportunizmu w analizowany zbiorze prac wykorzystuje się około 185 pytań. Wiele z nich jest tylko nieznacznie zmodyfikowanymi wersjami tego samego pomysłu, zmiany dotyczyły na przykład dostosowania do podmiotu, branży czy konkretnego rynku.

53 I. Staniec, Modelowanie równań strukturalnych w naukach o zarzq̨dzaniu „Organizacja i Kierowanie" 2018, t. 2(181), s. 65-77.

54 J.R. Brown, C.S. Dev, D.J. Lee, Managing Marketing Channel Opportunism... 


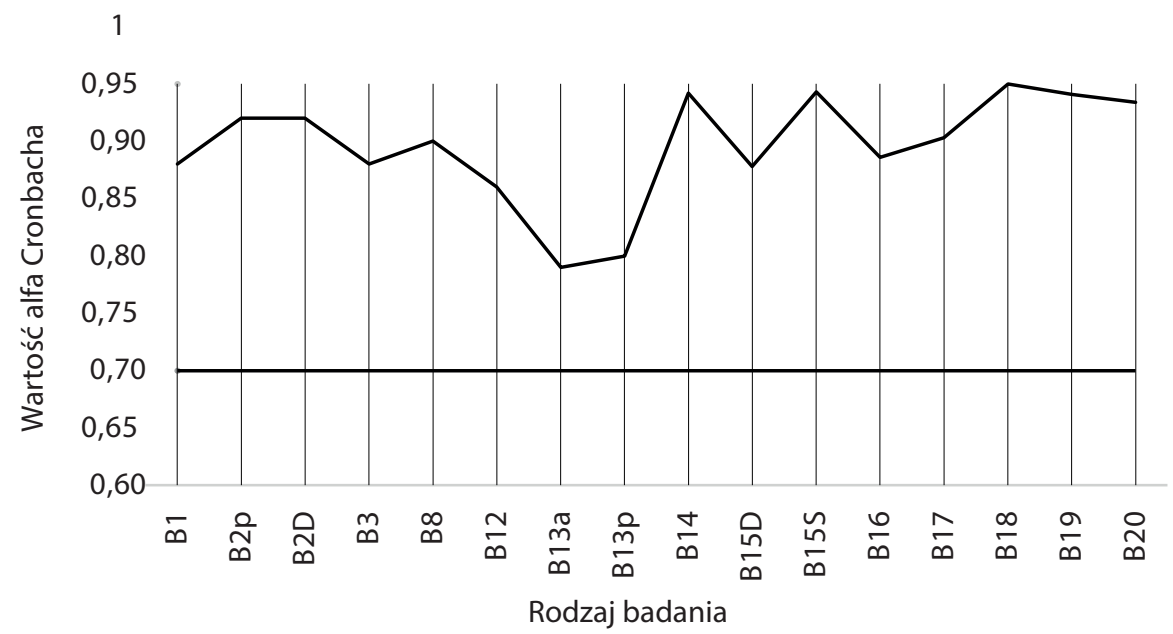

Cyfra po B oznacza liczbę porządkową badania z tabeli 1 oraz identyfikator badania; przedstawiono tylko badania, $w$ który podany byt ten współczynnik.

Rysunek 1. Wartości współczynnika alfa Cronbacha uzyskiwane w badaniach

Źródło: opracowanie własne.

Współczynnik alfa Cronbacha podano w czternastu analizowanych badaniach. Przedstawiane wartości mieszczą się w granicach od 0,7 do 0,95 wymaganych przez uwarunkowania teoretyczne. Najniższe wartości odnotowano w badaniu Seggiego, Griffitha i Jap55 (B13a i B13b), gdzie zastosowano inne podejście i oddzielny pomiar oportunizmu aktywnego i pasywnego. Badania nie wskazują na istotne różnice w wartościach tego współczynnika.

Miarę rzetelności $A V E$ przedstawiono w dwunastu badaniach, a $C R$ w trzynastu badaniach. Przedstawiane w pracach miary rzetelności $A V E$ i $C R$ osiągają wartości powyżej zakładanego w literaturze progu. Wyjątek stanowi badanie Gillilanda i Manninga ${ }^{56}$ (B6*), gdzie obie wartości są niższe $C R=0,69<0,7$ (zbliżona wartość), a $A V E=0,42$ $<0,5$. Autorzy uzasadniają te niższe wartości specyfiką branży gastronomicznej oraz brakiem wcześniejszych badań dotyczących tego obszaru. Drugi wyjątek stanowi w pierwszej fali badanie Heidego, Wathnego i Rokkana ${ }^{57}$ (B10ol), gdzie współczynnik $A V E=0,41<0,5$, ale w kolejnej fazie badań (B10o2) jego wartość osiągnęła już akceptowalny pułap. W przypadku $C R$ zróżnicowanie między badaniami nie jest istotne. Dla współczynnika $A V E$, oznaczającego wewnętrzną spójność narzędzia, występujące zróżnicowanie może wynikać z liczby pytań i ich rodzaju w narzędziu pomiarowym.

55 S.H. Seggie, D.A. Griffith, S. D. Jap, Passive and Active Opportunism...

56 D.I. Gilliland, K.C. Manning, When Do Firms Conform...

57 J.B. Heide, K.H. Wathne, A.I. Rokkan, Interfirm monitoring... 


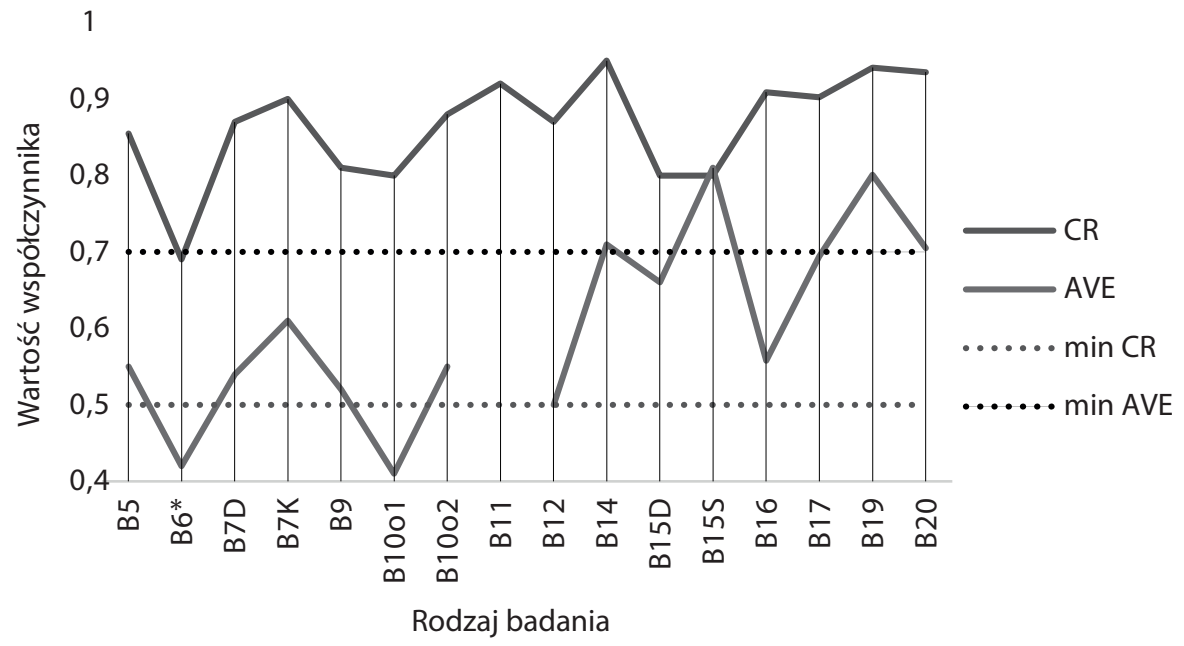

Cyfra po B oznacza liczbę porządkową badania z tabeli 1 oraz identyfikator badania; przedstawiono tylko badania, w który podany był ten współczynnik. * Zastosowano skalę pięciopunktową.

Rysunek 2. Wartości współczynników CR i AVE uzyskiwane w badaniach

Źródło: opracowanie własne.

\section{Analiza porównawcza wyników pomiaru}

W celu przeprowadzenia analizy porównawczej zdecydowano się na zaprezentowanie wartości średnich, odchylenia standardowego i typowych przedziałów zmienności dla wartości uzyskanych w ramach pomiaru konstruktu oportunizm w analizowanych badaniach (tabela 1).

Wyniki przedstawione na rysunku 3 pokazują, że typowe przedziały zmienności dla oportunizmu są poniżej neutralnego (środkowego) punktu skali Likerta zastosowanej w badaniach. Wyjątek stanowią badania: Dahlstroma i Nygaarda ${ }^{58}$ (B41994), Crosno i Dahlstroma ${ }^{59}$ w ujęciu dostawców (B15D) oraz Verbekego i wsp. ${ }^{60}$ (B18), gdzie wartości średnie są zbliżone do punktu neutralnego. Najwyższa ze wszystkich wartość konstruktu w badaniu Verbekego i wsp. ${ }^{61}$ (B18) wynika z podmiotu i przedmiotu badania dotyczącego wchodzenia firmy na nieznany dotąd rynek i to dla firm

58 R. Dahlstrom, A. Nygaard, An Empirical Investigation...

59 J.L. Crosno, R.F. Dahlstrom, An Empirical Investigation of Bilateral Investments and Opportunism in Buyer-Supplier Relationships, „Journal of Marketing Channels” 2016, no. 23, s. 146-156, http://doi.org/10.1080/1046669X.2016.1186473

60 A. Verbeke i wsp., Five Configurations...

61 Tamże. 
chińskich. Potwierdza to pogląd Williamsona ${ }^{62}$, że niepewność generuje wyższe postrzeganie oportunizmu. W przedstawionych badaniach większość respondentów wybrała zatem opcję poniżej punktu neutralnego. Ponadto w ponad jednej trzeciej badań średnia oportunizmu była jednoznacznie najniższa dla wszystkich konstruktów pojawiających się w badaniach mierzonych skalą Likerta.

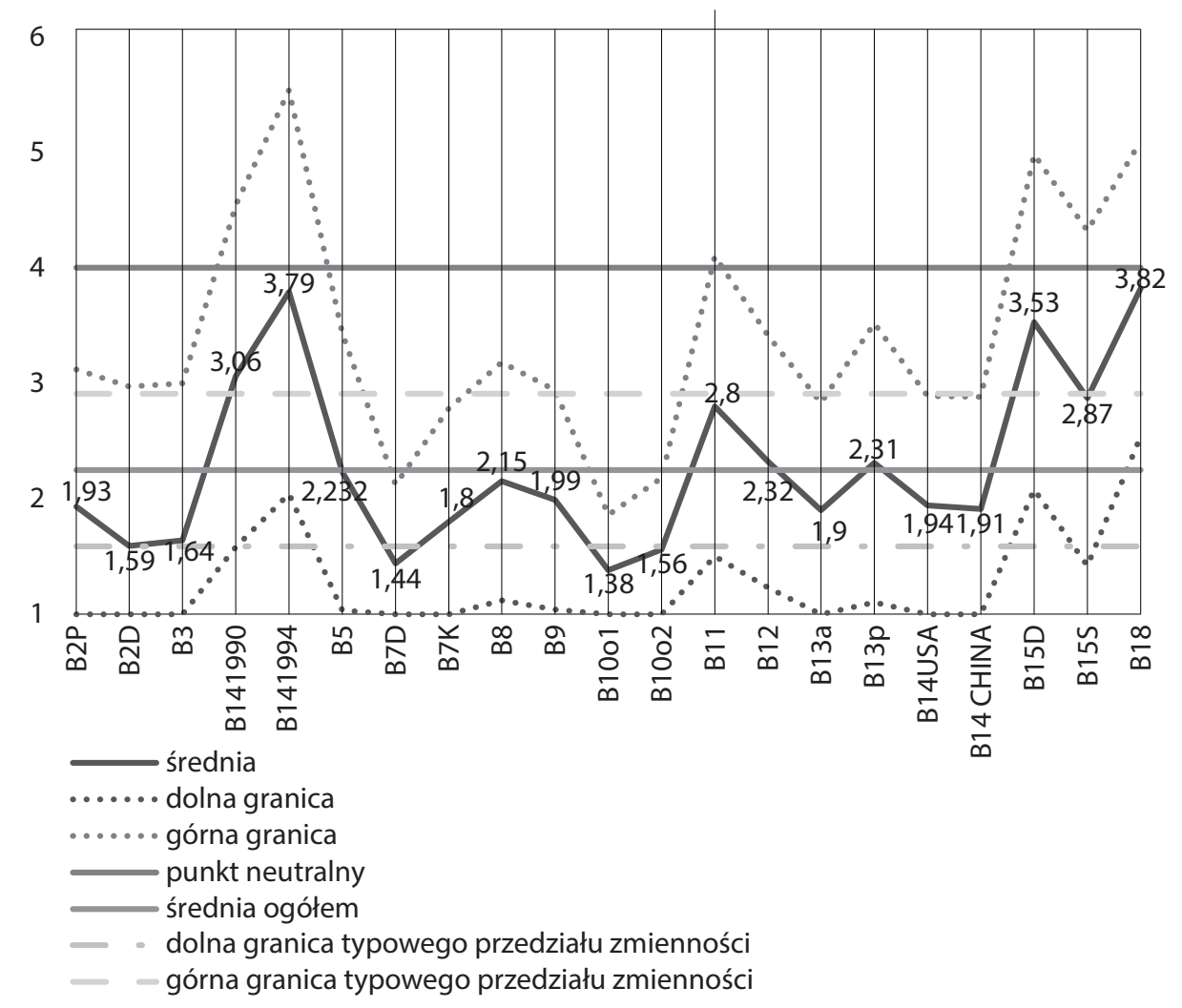

Cyfra po B oznacza liczbę porządkową badania z tabeli 1 oraz identyfikator badania.

Rysunek 3. Średnie i typowe przedziały zmienności dla konstruktu oportunizm w badanych zaprezentowanych w tabeli 1

Źródło: opracowanie własne.

W dalszym etapie, wykorzystując zasady metaanalizy, wyznaczono przeciętną wartość oportunizmu (średnią ogółem) dla wszystkich badań, która wynosi 2,25, oraz ryzyko nieosiągnięcia tej wartości (odchylenie standardowe), wynoszące 0,659 (jest niższe od 1 pkt). Wynika stąd, że oczekiwane wartości będą z dolnych skal pomiarowych. W związku z tym przedstawione wyniki potwierdzają, że podejrzenie

62 O.E. Williamson, The Economic Institutions... 
oportunizmu w relacji nigdy nie jest zerowe, jednak wartość tych podejrzeń jest względna niska. To potwierdza wynik prac Williamsona ${ }^{63}$ oraz Kelly’ego, Wagner i Ramsaya ${ }^{64}$.

\section{Podsumowanie}

Z zaprezentowanych wyników widać, że postrzeganie zachowań oportunistycznych jest niezależne od czasu - analizowane prace pochodziły z lat 1984-2018. W czasie, który upłynął od momentu przeprowadzenia oryginalnego badania do klejonego, z pewnością nastąpiły zmiany w zachowaniach organizacyjnych czy kulturze organizacji, choćby ze względu na wszechobecną cyfryzację. Rezultaty potwierdzają również przekonanie o tym, że duże znaczenie dla powtarzalności badań ma istotność statystyczna efektu odkrytego w oryginalnym eksperymencie. Okazało się bowiem, że mimo innych narzędzi pomiarowych, opartych na tej samej definicji, uzyskane wyniki są porównywalne. Nie występują istotne różnice w wartościach konstruktu, jakim jest oportunizm, mimo różnic w narzędziach pomiarowych. Wszystkie narzędzia pomiarowe mogą być zatem traktowane jako alternatywne miary. Jednym $z$ aspektów dalszych badań może być empiryczna weryfikacja tego zagadnienia, czyli zastosowanie przedstawionych skal pomiarowych do tej samej próby oraz zweryfikowanie uzyskanych różnic. Warto podkreślić, że ograniczeniem prowadzonych badań, oprócz zastosowanego doboru celowego czy wykorzystanej analizy treści, jest przeprowadzona metaanaliza. Jej heterogeniczność wynika z odmiennych metodyk badań (pojawiających się różnic w narzędziach pomiarowych), zróżnicowanych prób badawczych oraz różnorodnych okresów przedstawionych badań.

Bibliografia

Achrol R.S., Gundlach G.T., Legal and Social Safeguards Against Opportunism in Exchange, „Journal of Retailing" 1999, vol. 75(1), s. 107-124.

Anderson E., Transaction Costs as Determinants of Opportunism in Integrated and Independent Sales Forces, „Journal of Economic Behavior and Organization” 1988, no. 9, s. 247-264.

Babbie E., Badania spoteczne w praktyce, Wydawnictwo Naukowe PWN, Warszawa 2003.

Bernstein B., Socjolingwistyka a spoteczne problemy ksztatcenia, [w:] M. Głowiński (red.), Język i społeczeństwo, Wydawnictwo Czytelnik, Warszawa 1980, s. 83-116.

63 O.E. Williamson, Opportunism and Its Critics, „Managerial and Decision Economics” 1993, vol. 14(2), s. 97-107, http://doi.org/10.1002/mde.4090140203

64 W publikacji S. Kelly, B. Wagner, J. Ramsay, Opportunism in buyer - supplier exchange... przeanalizowano wartości średnie dla każdego pytania, a nie uogólnione miary konstruktu. Autorzy doszli do tych samych wniosków. 
Brown J.R., Day R.L., Measures of Manifest Conflict in Distribution Channels, „Journal of Marketing Research" 1981, no. 18(August), s. 263-274.

Brown J.R., Dev C.S., Lee D.J., Managing Marketing Channel Opportunism: The Efficacy of Alternative Governance Mechanisms, „Journal of Marketing” 2000, no. 64(April), s. 51-65.

Crosno J.L., Dahlstrom R.F., An Empirical Investigation of Bilateral Investments and Opportunism in Buyer-Supplier Relationships, „Journal of Marketing Channels” 2016, no. 23, s. 146-156, http://doi.org/10.1080/1046669X.2016.1186473

Czakon W., Metodyka systematycznego przegladu literatury, „Przegląd Organizacji” 2011, nr 3, s. 57-61.

Czakon W., Tworzenie teorii w naukach o zarzqdzaniu, [w:] A. Sopińska, P. Wachowiak (red.), Wyzwania wspótczesnego zarzqdzania strategicznego, Oficyna Wydawnicza SGH - Szkoła Gtówna Handlowa w Warszawie, Warszawa 2017, s. 143-160.

Czakon W., Walidacja narzędzia pomiarowego w naukach o zarzq̨dzaniu, „Przegląd Organizacji” 2019, nr 4, s. 3-10, http://dx.doi.org/10.33141/po.2019.04.01

Dahlstrom R., Nygaard A., An Empirical Investigation of Ex post Transaction Costs in Franchised Distribution Channels, „Journal of Marketing Research” 1999, no. 36(May), s. 160-170.

Dwyer F.R., Oh S., Output Sector Munificence Effects on the Internal Political Economy of Marketing Channels, „Journal of Marketing Research” 1987, no. 24(November), s. 347-358.

Gilliland D.I., Manning K.C., When Do Firms Conform to Regulatory Control? The Effect of Control Processes on Compliance and Opportunism, „Journal of Public Policy \& Marketing” 2002, no. 21, s. 319-331.

Goetz C.J., Scott R.E., Principles of Relational Contracts, „Virginia Law Review” 1981, vol. 67(6), s. $1089-1150$.

Gundlach G.T., Achrol R.S., Mentzer J.T., The Structure of Commitment in Exchange, „Journal of Marketing" 1995, no. 59(January), s. 78-92.

Heide J.B., Wathne K.H., Rokkan A.I., Interfirm monitoring, social contracts, and relationship outcomes, „Journal of Marketing Research” 2007, vol. 44(3), s. 425-433.

Jap S. D., The Impact of Online Reverse Auction Design on Buyer - Supplier Relationships, „Journal of Marketing" 2007, no. 71(January), s. 146-159.

Jap S. D., Anderson E., Safeguarding interorganizational performance and continuity under ex post opportunism, „Management Science” 2003, vol. 49(12), s. 1684-1701.

John G., An Empirical Investigation of Some Antecedents of Opportunism in a Marketing Channel, „Journal of Marketing Research” 1984, vol. 21(3), s. 278-289.

Karpacz J., Oportunizm w relacjach międzyorganizacyjnych w teorii i praktyce, „Prace Naukowe Uniwersytetu Ekonomicznego we Wrocławiu" 2014, nr 366, s. 236-247.

Kashyap V., Antia, K.D., Frazier G.L., Contracts, extra contractual incentives, and ex post behavior in franchise channel relationships, „Journal of Marketing Research” 2012, vol. 49(2), s. $260-276$.

Kelly S., Wagner B., Ramsay J., Opportunism in buyer - supplier exchange: a critical examination of the concept and its implications for theory and practice Production Planning \& Control, „The Management of Operations” 2018, vol. 29(12), s. 992-1009, http://doi.org/10.1080/09 537287.2018.1495772

Lianying Z., Qinzhen Q., How mediated power affects opportunism in owner-contractor relationships: The role of risk perceptions, „International Journal of Project Management” 2017, vol. 35(3), s. 516-529.

Lu P., Qian L., Chu Z., Xu X., Role of opportunism and trust in construction projects: empirical evidence from China, „Journal of Management Engineering” 2015, vol. 32(2), s. 1-10. 
Lu W., Zhang L., Zhang L., Effect of contract completeness on contractors' opportunistic behavior and the moderating role of interdependence, „Journal Construction Engineering Management" 2016, vol. 142(6), http://doi.org/10.1061/(ASCE)CO.1943-7862.0001110

Luo Y., Opportunism in interfirm exchange in emerging markets, „Management \& Organization Review" 2006, vol. 2(1), s. 121-147.

Muris T.J., Opportunistic Behavior and the Law of Contract, „Minnesota Law Review” 1981, no. 65, s. 521-590.

Provan K.G., Skinner S.J., Interorganizational Dependence and Control as Predictors of Opportunism in Dealer-Seller Relations, „Academy of Management Journal” 1989, no. 32(March), s. 202-212.

Rokkan A.I., Heide J.B., Wathne K.H., Specific Investments in Marketing Relationships: Expropriation and Bonding Effects, „Journal of Marketing Research” 2003, no. 40(May), s. 210-224.

Seggie S.H., Griffith D.A., Jap S. D., Passive and Active Opportunism in Interorganizational Exchange, „Journal of Marketing” 2013, vol. 77(6), s. 73-90, http://doi.org/10.1509/jm.11.0529

Skarmeas D., Katsikeas C.S., Schlegelmilch B.B., Drivers of commitment and its impact on performance in cross-cultural buyer-seller relationships: the importer's perspective, „Journal of International Business Studies" 2002, no. 33, s. 757-783.

Staniec I., Modelowanie równań strukturalnych w naukach o zarzq̨dzaniu „Organizacja i Kierowanie" 2018, t. 2(181), s. 65-77.

Szczepaniak K., Zastosowanie analizy treści w badaniach artykułów prasowych - refleksje metodologiczne, „Acta Universitatis Lodziensis. Folia Sociologica” 2012, nr 42, s. 83-112.

Um K.H., Kim S. M., Collaboration and opportunism as mediators of the relationship between NPD project uncertainty and NPD project performance, „International Journal of Project Management" 2018, vol. 36(4), s. 659-672, http://doi.org/10.1016/j.ijproman.2018.01.006

Verbeke A., Ciravegnad L., Lopeze L.E., Kunduf S.K., Five Configurations of Opportunism in International, Market Entry, „Journal of Management Studies” 2018, http://doi.org/10.1111/jo ms.12355

Wathne K.H., Heide J.B., Opportunism in Interfirm Relationships: Forms. Outcomes, and Solutions, „Journal of Marketing” 2000, no. 64(October), s. 36-51.

Williamson O.E., Opportunism and Its Critics, „Managerial and Decision Economics” 1993, vol. 14 (2), s. 97-107, http://doi.org/10.1002/mde.4090140203

Williamson O.E., The Economic Institutions of Capitalism, The Free Press, New York 1985.

Williamson O.E., The Mechanisms of Governance, Oxford University Press, New York 1996.

Williamson O.E., Transaction Costs Economics: The Governance of Contractual Relationships, „Journal of Law and Economics” 1979, no. 22, s. 223-260.

Wuyts S., Geyskens I., The Formation of Buyer - Supplier Relationships: Detailed Contract Drafting and Close Partner Selection, „Journal of Marketing” 2005, no. 69(October), s. 103-117.

Yan T., Kull T.J., Supplier Opportunism in Buyer-Supplier New Product Development: A China U.S. Study of Antecedents, Consequences, and Cultural/Institutional Contexts, „Decision Sciences" 2015, vol. 46(2), s. 403-444.

You J., Chen Y., Wang W., Shi Ch., Uncertainty, opportunistic behavior, and governance in construction projects: The efficacy of contracts, „International Journal of Project Management” 2018, no. 36, s. 795-807.

Zhang C., Li J., Huang Y., Sustaining relationships after opportunism and misunderstanding: the role of formalization and socialization, „Marketing Letters” 2017, vol. 28(2), s. 305-319, http:// doi.org/10.1007/s11002-016-9414-1 


\section{Streszczenie}

Rozdział ma charakter przeglądowy i jest oparty na badaniu praktyk stosowanych w zakresie pomiaru oportunizmu. W pracy zastosowano dobór celowy. Opracowanie przedstawia narzędzia pomiaru zjawiska oportunizmu, stosowane w badaniach empirycznych. Wyniki badań wskazują, że nie ma jednego przyjętego narzędzia pomiaru tego zjawiska. Jednak - co jest istotne z punktu widzenia replikacyjności tych badań - otrzymywane wartości pomiaru zjawiska oportunizmu wskazują, że jego natężenie jest niskie. We wszystkich podejściach oportunizm traktowany jest jako wielowymiarowy konstrukt, w którym liczba wymiarów oraz sposób pomiaru każdego z nich może być różny.

Słowa kluczowe: oportunizm, narzędzia pomiaru, analiza porównawcza

\section{Comparability in Opportunistic Behavior}

\section{Abstract}

The article is a review and based on the study of practices used to measure opportunism. The targeted selection was used in this paper. The purpose of the paper is to present the tools for measuring the phenomenon of opportunism used in empirical research. Research results indicate that there is no single accepted tool for measuring this phenomenon. However - which is important from the point of view of replicability of these studies - obtained values of measurement of the phenomenon of opportunism indicate that its intensity is low. In all approaches, opportunism is treated as a multidimensional construct in which the number of dimensions and the way of measuring each of them can be different.

Keywords: opportunism, measurement tools, comparative analysis 